\title{
ILLUSTRIOUS PHYSICIANS AND SURGEONS IN IRELAND.
}

\author{
No. IV.
}

\author{
JOHN RUTTY, M. D.
}

IT has been often remarked, how unjustly fortune acts in the disposition of her favours amongst the members of the medical profession, and how frequently prosperity is withheld from sterling merit, while it appears, in some instances, to be capriciously and profusely granted to the undeserving $(a)$. The same remark may be applied with perhaps still greater justice to the reputation awarded by posterity to the cultivators of medical science. In how many instances have the real labourers in science been not only unrequited during life, but forgotten after death? That this should very generally happen to those engaged in the service of that untutored and ungrateful master, the Public, is no more than what is to be expected by all who consider the materials of which that Public is composed. But it is surely matter of reproach, when the members of our enlightened profession, suffer the unrighteous verdict of the world, in a matter which concerns them, to be recorded without appealing against it ; and this they do when they permit the memoly of the true cultivators of medical science to pass away into oblivion, without, at least, testifying their sense of the debt due to them as benefactors and instructors of mankind. The plan which has been carried into effect in this Journal, of publishing memoirs of the physicians belonging to this country, is, indeed, no more than an act of justice too long deferred; and this is more peculiarly the case in those instances where to the merits of the physician are to be added the virtues of the man. In the character of Dr. John Rutty, whose memoir we are now about to trace, we shall find an unceasing ardour in the advancement of science, combined with an endeavour to attain to the highest order of moral excellence. Such a character is not alone our property; it belongs to mankind: and in endeavouring to disinter the particulars of his life and labours from the obscurity and oblivion in which they are now nearly lost, we feel that we discharge no less a duty to the present race of his professional brethren, than to that country for the illustration and improvement of which he so long and so faithfully laboured.

Dr. John Rutty was born on the 25th of December, 1697. The place of his birth we have not been able with certainty to ascertain; but it appears to have been in some part of Wiltshire, where his family was settled; neither are we informed as to the occupation of his father. He appears to have been born and educated among the Quakers; and relates in his Diary, that, after being from his

(a) We are indebted to our learned friend and contributor, Dr. Jonathan Osborne, Professor of Materia Mediea to the School of Physic, for the materials of this interesting memoir of Dr. Rutty. 
thirteenth to his eighteenth year at various mixed schools, "among aliens, living as without God in the world, intent all the while on his learning," he was about his twentieth year transplanted to "a family of Friends." There some inclination to marriage was "overruled by a secret hand," and he continued a bachelor to his death. About his twenty-second year he removed to London, and, most probably attracted by the celebrity of Boerhaave, went to Leyden, where he graduated. His Diary states his object at this time "was all nature and physic, also serious thoughts of proper qualifications for a livelihood, as he had scarce any patrimony."

In 1720 he wrote a paper in the Philosophical Transactions upon Spina Bifida.

In 1724 he came to Dublin, and in 1729 was enrolled as a licentiate of the King and Queen's College of Physicians. For above twenty years after his arrival we are uninformed as to his practice in the profession; but from the commencement he kept a regular diary of the weather, and, at the same time, " opened a scheme for the improvement of the Materia Medica," to which branch of medical science he was peculiarly devoted throughout the entire of his long career.

His first publication was a new edition of Wight's History of the Quakers in Ireland, with a continuation of it from the year 1700 to $175 \mathrm{l}$; and to this he subjoined a treatise on the discipline exercised in that Society, which appeared in quarto in 1751.

In 1753 he began to keep a Spiritual Diary, which was published after his death, and has afforded us an insight into his cha. racter, not usually accorded to the writers of biography. It is remarkable for its quaintness of expression; and passages frequently occur, well calculated to provoke a smile; but its rare and distinguishing excellence is its honesty. He spares not himself, nor does he, as is the case in so many modern productions of this class, reap a rich harvest of pride out of assumed humility, or affect to labour under peculiar weaknesses, which all turn out to be so many cardinal virtues, or Christian graces, in disguise; on the contrary, we find him minutely dwelling upon his faults, with a view to their rectification, and to his greater advancement towards that religious perfection which was the object he constantly held in view. In his will he directed this work to be published; and in a short preface, after alluding to the restraint imposed on St. Teresa, when, in publishing a similar work, she was prevented by her spiritual directors from describing many of her faults, except in a general way in her preface, he says, that his "plan has been to enter minutely into the corruptions of the human heart," and he wishes his reader, in "observing the power and prevalence of sin, as maintaining its strong hold for a series of years, to be assured, that sanctification is not the work of a day, nor a week, nor a year; and that the Christian warfare ceaseth not but with our lives."

In 1757 he published, by subscription, his work on the Mineral Waters of Ireland, which comprised a series of inquiries and experiments carried on for many preceding years. His analysis was the 
best that the chemistry of the time afforded; and, in a great number of cases, he evaporated the water in order to ascertain the quantity of saline contents. His tests for chalybeates were solutions of galls, logwood, or sumach; and he perceived the important distinction between those which only answered to the tests when freshly taken from the source, but ceased to do so afterwards, and those which continued to retain the iron in solution. In ascertaining the other ingredients of this class, he also used soap, sulphuric and muriatic acids, syrup of violets, and nitrate of silver. For the vitriolic waters, in addition to the above, he immersed plates of silver or iron, and thus was able to ascertain the presence of copper in those of Nobber, Kilbrew, Ballycastle, Ballymurtagh, and Cronebawn. For the alkaline waters he also used vinegar to produce effervescence, and likewise muriate of ammonia, and in some cases resorted to the odour produced by bringing them in contact with red-hot iron. The sulphureous waters were principally tested by the acetate of lead. The following list of the waters described in the work cannot be uninteresting, and may be useful in exciting attention and inquiry towards them on the part of those medical gentlemen who may be resident in their neighbourhood.

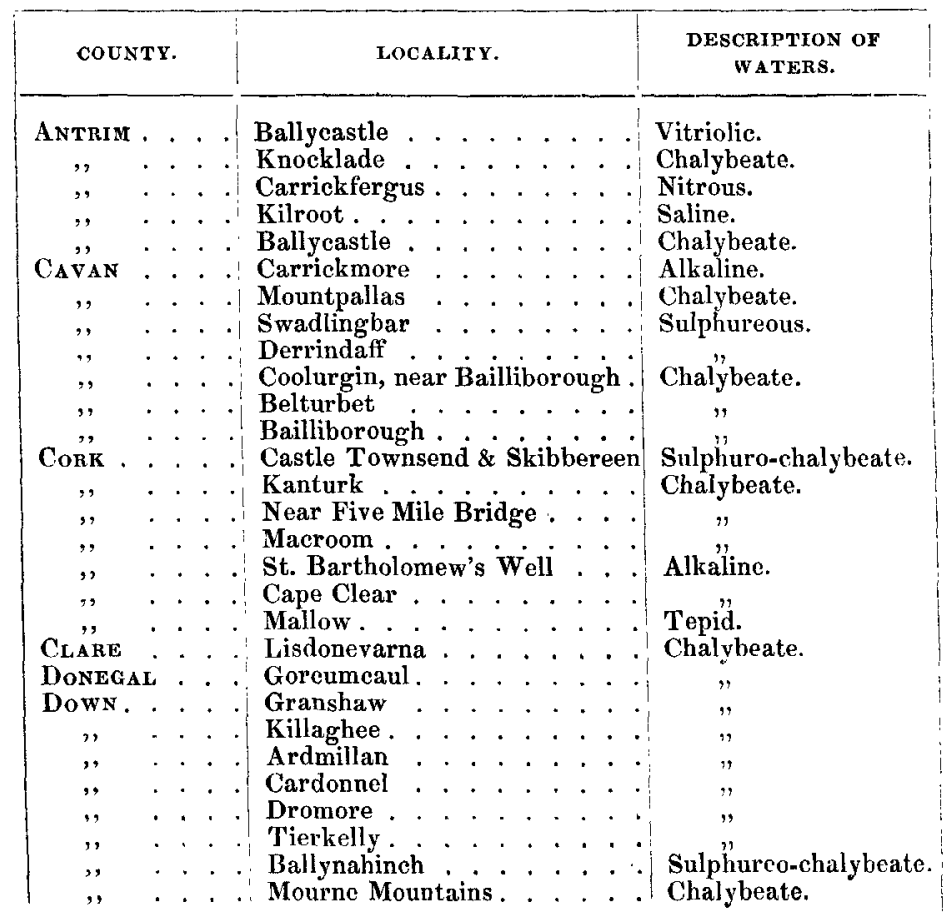




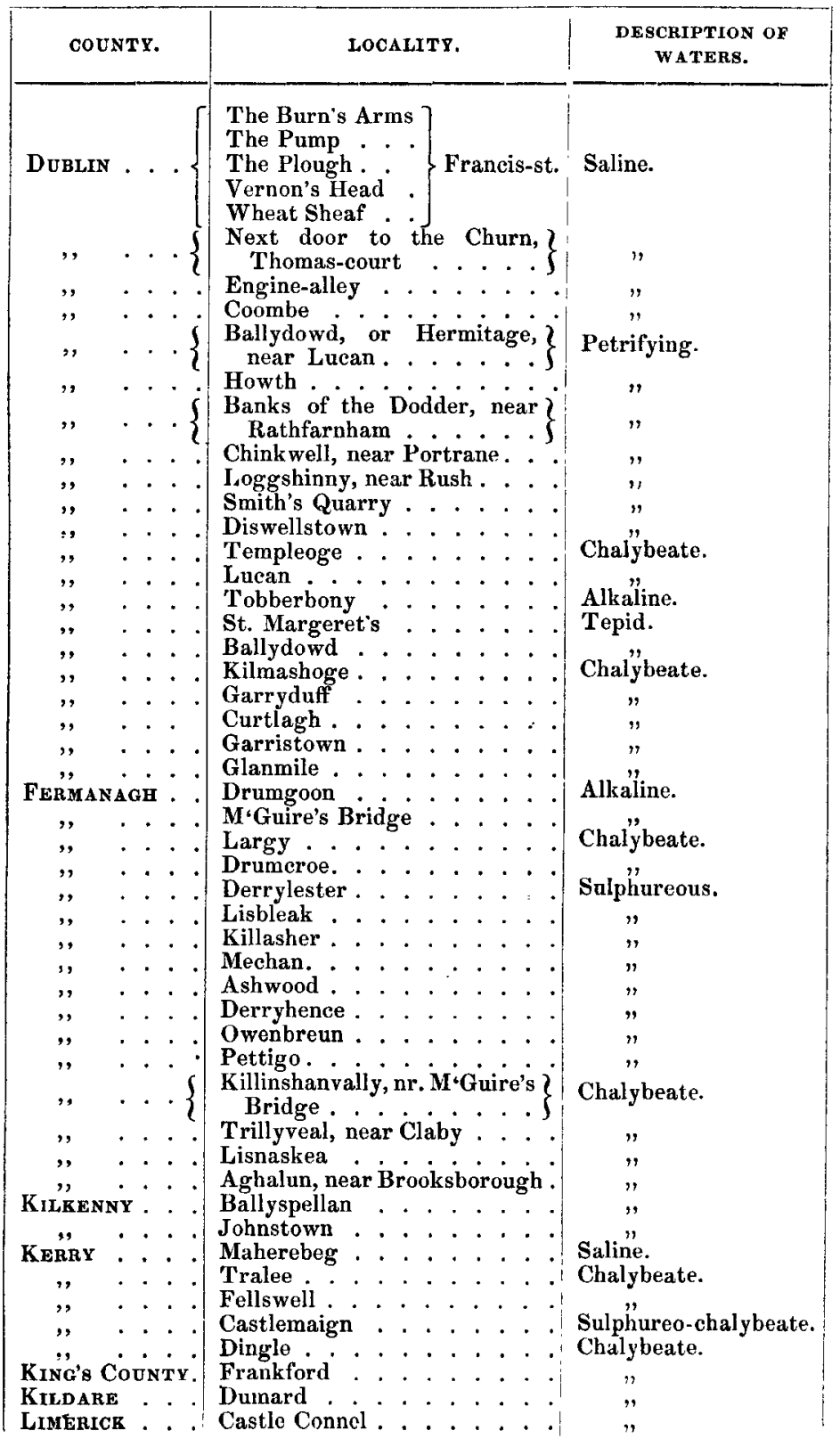




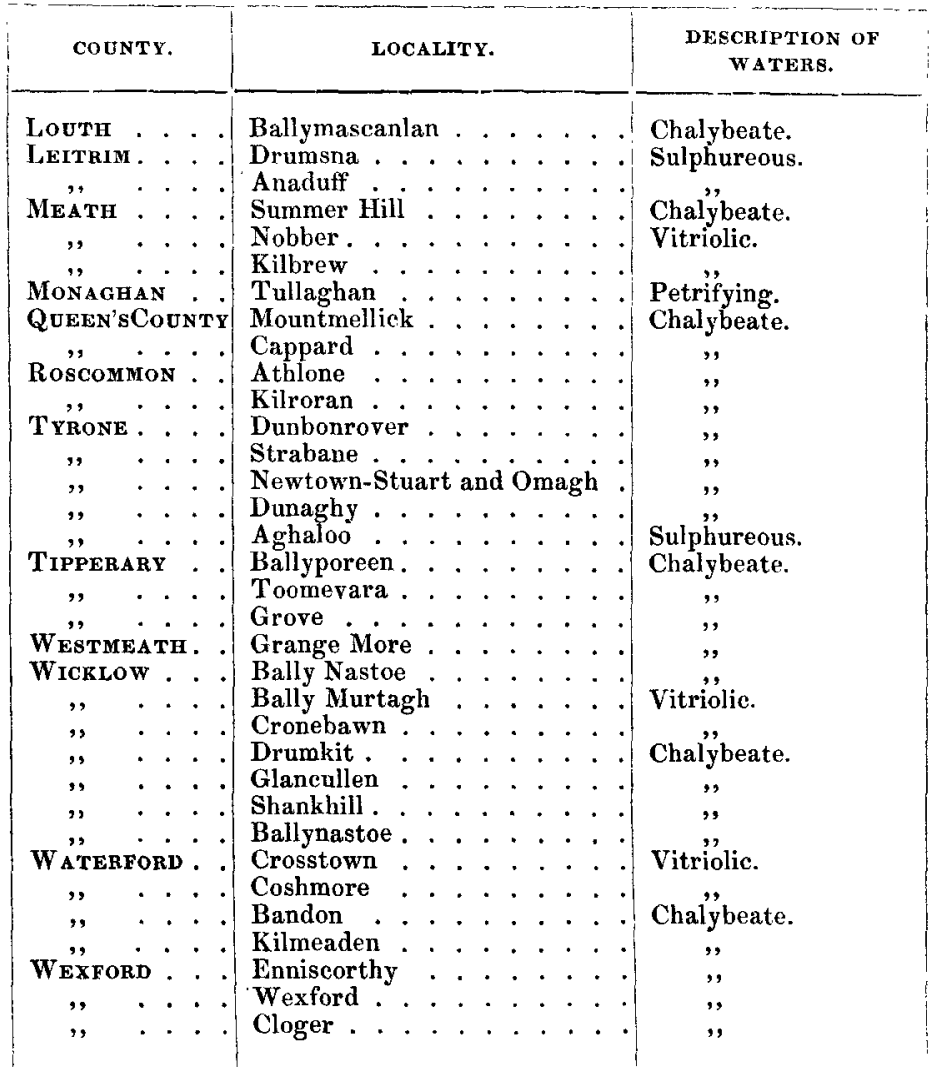

Mineral waters were in high favour with the public at the time when this work appeared $(a)$. The saline waters of Francis-street, in Dublin, were used at the close of the seventeenth century, but had become neglected, till revived in consequence of the researches of the Physico-Historical Society. From his experiments they appear to have contained an alkaline carbonate, common salt, and nitre; and, to produce any sensible effect, it was requisite to drink no less than four or five pints. It is probable that most, if not all, their saline contents were derived from decomposition of animal matters, conveyed to them through sewers or land-drains; but spas of any kind were at this time considered as of such value, that nothing short of full experience to the contrary could disturb

(a) It is to be regretted that Dr. Knox, in his work on Irish WateringPlaces, did not avail himself more extensively of the abundant material contained in Rutty's various works on this subject. 
their hold on the public mind. The chalybeate water of 'Templeogue was daily brought into town, and vended in St. Stepheu'sgreen. We find the unhappy Stella residing at one time at Templeogue, and afterwards at Wexford, to obtain the benefit of chalybeates, when she was labouring under the "hope long deferred." The spring of Ballyspellan was in such high repute when Dr. Taafe published his Treatise on it in 1724, that it was emphatically called "The Irish Spa." Dr. Sheridan's poem is in the recollection of all readers of Swift. It begins with:

"All ye that would refine your blood As pure as famed Lewellyn,

By waters clear, come every year To drink at Ballyspellin.

Continuing the same rhymes, he ends his fifteenth verse thus:

"My rhymes are gone, I think I've none,

Unless I should bring hell in ;

But since I'm here to heav'n so near, I can't at Ballyspellin."

This produced a rejoinder from Swift, beginning with:

" Dare you dispute, you saucy brute, And think there's no repelling

Your scurvy lays, and senseless praise, You give to Ballyspellin?"

It continues the same rhymes through fifteen verses, each ending with Ballyspellin, most of them unfit to be quoted, and was believed to have occasioned the breach between them, that was never made up.

Even Rutty departs from his usual sobriety, and, in his observations on the chalybeate water near Gorey, quotes the following verse of a song on it:

$$
\begin{aligned}
& \text { " Consumptive lad, } \\
& \text { With asthma bad, } \\
& \text { Grew rampant and picqueering; } \\
& \text { And widow pale, } \\
& \text { From head to tail, } \\
& \text { Was cured at Tobberneering." }
\end{aligned}
$$

A general neglect of the mineral waters of Ireland has taken place from the close of the last century up to the present time, and unmeritedly so with regard to several of the sulphureous and chalybeate springs, which, in many instances, are sufficiently impregnated for all practical purposes. Many of them are, moreover, situated in healtllful and beautiful localities. The general deficiency, however, of accommodation suited for invalids, and the want of any notable thermal or saline aperient waters, have caused them to be overlooked altogether by the squadrone volante of fashionable valetudinarians, a circumstance much to be deplored in a national point of view.

This work on the mineral waters was not received by the public as the anthor had a right to expect. The following reflection occurs 
in his Jiary, 10th 12 th mo, 1757: "On the printing and sale of my book, O how was I deceived as to its reception! Few but subscribers came, and had it not been for those, I had suffered greatly in the expense : learn then the worth of the world."

It was immediately attacked by the celebrated Dr. Lucas, who, before acquiring notoriety as a patriot, had published in London, in 1756 , an Essay on the properties of mineral waters in general. 'This work, entitled, an "Analysis of Dr. Rutty's Medical Synopsis of Mineral Waters," produced a reply from Rutty, and a controversy ensued, which lasted during three years. Several able pamphlets were written on this occasion, but, generally speaking, Lucas had the best of it; still we find Rutty maintaining his temper:-thus in his Diary, 9th 8 th mo., 1757, we read: "Was this day presented with Lucas's sarcastical remarks on my book. This is a wholesome discipline, though severe: a controversy ensued. God mingles trouble with pleasure. 'There are some imperfections and errors in my work, I thank God he had found no more." And when he had occasion to mention Dr. Lucas subsequently, in his work on the County of Dublin, he calls him the "ingenious Dr. Lucas;" and in other places speaks of him with consideration and respect.

As we intend presenting our readers with a biography of Charles Lucas shortly, we will not now enter into the subject of this controversy, but reserve it for another occasion. Among the tracts connected with this controversy we have met the following: "The Argument of Sulphur or no Sulphur in Waters discussed;" $(a)$ in which " the phlogiston, sulphur, and oily matter, according to Dr. Lucas, as defended in his essay," were impugned. In this work Rutty was assisted in his chemical experiments by Dr. F. Hutcheson, the Professor of Chemistry, and by Mr. Patrick Bride. This was answered by Lucas in a few months by a very caustic pamphlet, styled "A cursory Examination of the Methodical Synopsis, \&c., and of the Argument of Sulphur or no Sulphur, \&c., in a letter to the celebrated John Rutty, M. D., seriously recommended to the Perusul of the reading Subscribers to the Doctor's Work." $(b)$ This again was answered by two friends of Rutty; by the first in a small tract of fifteen pages, entitled, "Cursory Remarks on a "Cursory Examination,' \&c. By Theophrastus Antiphlogisticus;"(c) and the second by "A Letter to a Friend in Dublin, containing some Remarks on the 'Cursory Examination,' \&c. By an Apothecary."' $(d)$ Abont the same time "The Author of the Manufacture of Drugs" mingled in the fray, in a tract which he published on " An artificial sulphureous Water resembling the Natural, a Thing hitherto supposed

(a) Dublin, M‘Culloh. 1762. pp. 109.

(b) Dublin, Ewing. 1763. pp. 87. Finding that many of the writings of the Dublin physicians, particularly about the middle of the last century, are not only unknown but exceedingly scarce, we purpose affixing to each of these memoirs of medical men a list of their various writings, \&c.

(c) Dublin, Saunders. 1763 .

(d) Dublin, printed in the year 1763. pp. 21. There is no printer or pullisher's name to this, but it is dated Belfast, 10th April, 1763. 
impracticable in Chemistry." $(a)$ Within three weeks from the issue of this pamphlet Lucas published a powerful reply, both to it and the two preceding tracts, in a "Second Letter to the learned and ingenious Dr. Rutty." $(b)$

Along with the "Sulphur or no Sulphur" work, with which they were printed, appeared, "The Analysis of Milk, and the several Species thereof, by John Rutty, M. D.;" and also "A practical Dissertation on the Uses of Goat's Whey," a tract furmished to Rutty by Dr. James Kennedy of Downpatrick. Did our space permit, we would wish to present our readers with some notice of those very rare works. We shall not, however, lose sight of the subject.

The observations which he had made on the weather and prevailing diseases of Dublin, and the results of which he communicated on several occasions to the Physico-Historical Society, and elsewhere, formed the chief materials of his "Chronological History of the Weather and Seasons, and the prevailing Diseases in Ireland," published in London in 1770. His Diary of the Weather was commenced in 1725, and was continued without interruption till 1765 , except during the summer of 1737 , when, during his absence in England, it was kept by Dr. Richard Weld.

In this work, besides the fevers that are briefly described under each year, the following epidemics are more peculiarly remarkable, viz.: in November, 1729, an epidemic catarrh, fatal to most old persons; November, 1739, a similar disease, passing from Germany through Great Britain, and peculiarly fatal to children. After the hard frost which commenced in December, 1739, and lasted to the middle of February, 1740, the summer was attended by small-pox and dysentery. The winter of 1740 remarkable for a famine, owing to a failure in the potatoe crop, followed by typhus during the dry and hot summer that succeeded. This is described by O'Connell, who computed that, during 1740 and 1741, the number of those who died of famine, fever, and dysentery, amounted to 80,000 . 1743 an epidemic croup, sweeping off the children of whole villages in the southern and midland counties, and apparently the same disease as that described by Dr. Fothergill in London at the same time, as the putrid sore throat $(c)$. Summer of 1735 , and spring of 1754, agues. 1751 and 1760, distemper among horses. 1762, influenza, traced as having passed through Great Britain from Copenhagen. By the numbers of burials recorded, there is the most striking evidence of the fatality of influenza, and also of the truth of his general observation, that the greatest mortality in Dublin occurred in those years in which there was the least moisture.

The Physico-Historical Society, of which we have already given an account, having committed to him the investigation of the natural history of the county Dublin, he appears to have made it

(a) Dublin, Williamson. March, 1763. pp. 23.

(b) Dublin, G. and A. Ewing. pp. 59. March 30th, 1763.

(c) See Medical Memoir to Irish Census for 1841 , pp. viii -xxiv, for a general account of all these epidemics. 
the occupation of his walks and hours of recreation for many years; but it was not till the year 1772 that he published it. It is in two volumes, and dedicated to the Dublin Society. He obtained thirty pounds from the College of Physicians to help to defray the expenses, and there appears a list of 350 subscribers. At the commencement he takes a view of the situation of the city of Dublin, and the following description of the scenes which afforded recreation and enjoyment to our predecessors so many years ago, can hardly be read without interest now :

"This city enjoys a situation for pleasantness hardly to be equalled, whether one would entertain himself with a survey of the artificial beauties on the western side in the many public buildings which adorn it, among which I shall only mention two which were the foundations of private persons, because they do honour to human nature, particularly the hospital founded by Dr. Steevens, and that for lunatics and idiots by Dr. Jonathan Swift; or if on the same western side he would choose to survey the natural beauties, he may take a ride to the deer-park contiguous to the city, and direct his course along the banks of the Liffey, extending several miles up the country, frequently adorned with hills and gentle declivities, partly wild and partly interspersed with woods, and sometimes with corn-fields and pensile gardens, exposed to the south, which supply the city with pease a week or fortnight earlier than colder situations. (a) Or if he would divert himself with a walk, he hath his choice of three very agreeable ones, viz.: one to the south-east, to that called Stephen's-green, said to be one of the largest squares in Europe; a second to the east and north-east, being that part of the Strand which is lately reclaimed from the ocean by a vast bank, called the North-wall; the third, to the west, on the bank of the Bason, or great reservoir of water for the city; which said several walks may be said to vie with each other in delightfulness. Again, on the north side of the city are numerous gardens, supplying the inhabitants with their produce; and if we travel further northward, and nearer the coast, we have the sea frequently and beautifully intersected with islands; or if, in another position, we take a view from the south-west to the south-east, our sight is agreably bounded with a range of mountains, making up almost a semicircle, some of which seem to pierce the skies $(b)$ with their awful and magnificent summits: so that, upon the whole, which way soever one turns his eyes, a situation more delightful, or a greater variety of pleasing objects can hardly be conceived."

(a) The present Strawberry Banks.

(b) This may refer to Sugarloaf, which, in the View of Dublin, appended to the rare map published in 1728 , is represented with a slender conical summit, terminating almost in a point. This mountain is altogether composed of quartz rock, and a remarkable proeess of disintegration has gone on at its summit, producing a vast mass of debris, principally on the western face of the cone. How far the actual form of the mountain may have been thus altered within a short period of time would be an interesting inquiry to the geologist.

v OL. II. No. 6, N. s. 
The descriptions of the uses and applications of vegetables, indigenous or cultivated in the district, are excellent, and derived both from reading and his own observation. It strongly suggests the value of a work on the same subject, suited to the wants and habits of the present time, but is also an evidence of the difficulty of effecting improvement among the great masses of our people. As an instance, he describes the uses to which the ashes of the full-grown thistle are applicable as an alkali; and yet, although it has been proved that those ashes contain above thirty-five per cent. of potash, yet we never see them collected or lixiviated; and they are very generally not even pulled up, or placed to rot on a dunghill, till after they have shed their seeds and secured a succession of noxious weeds over the surrounding country. In this part of the work are many melancholy instances of the vain efforts made by the Dublin Society, and other patriotic bodies, to stimulate indolence into activity by premium and bonus, proving that the true industrial resources of a country consist, not in its soil, or its water power, or its minerals, but in the truth and integrity, the energy and perseverance of its inhabitants.

The description of the economic uses of so many productions of nature going to waste around us, is, however, well suited to illustrate how much it is in the power of the physician to be of use to his fellow-creatures, not only by the exercise of his benevolent vocation of healing the sick, but by the application of his knowledge of the material world to their general advantage and enjoyment.

In the zoological department there are plates of the bull's-eye, the cherrychirper, the ska, the cock widgeon, the easterling, and the popjack diver. The account of fish is the most defective. Under the head of minerals he has bestowed the greatest pains in his observations and experiments on clays and marls, and, next to them, on those kinds of stone which furnish materials for the builder. He in this work also resumed the subject of mineral waters, and has given a series of experiments on the water of St. Patrick's Well at Finglas, contrasted with Malvern Waters; also a series of experiments made annually on the springs of Francis-street, during the twelve years that had elapsed since the publication of his work on Mineral Waters. These shew the saline contents to vary so much as to leave but little doubt that their impregnation was from extrinsic and accidental sources.

The chalybeate spa of Lucan mentioned in the "Mineral Waters" was that which exists at present, at a short distance to the left from the high road entering the village from Dublin; but in the year 1758, that is a year subsequently to the publication of that work, the present sulphureous spa, near the river, in Mr. Vesey's demesne, was discovered, and soon came into high repute. The water was conveyed to Steevens' Hospital for the service of the patients, and he has arranged the cures performed by it under the heads of cutaneous diseases, ulcers, scrofulous cases, and diseases of the first passages; and he has not omitted a decidedly unfavourable case, in which, he says, the remedy was used " because it began to be modish, rather than 
from proper advice;" adding, "that a few such cases must have blasted the reputation of this inestimable spring for ever, had they not been confronted by such a multitude of indisputable instances of its good and powerful effects."

In the zoological department of this work there is not much originality. The author has, however, successfully followed up, for the county of Dublin, what had been previously effected by Harris for Down, and Smith for Cork and Waterford. And the letters S. and H., prefixed to so many of his descriptions, shew how largely he availed himself of the knowledge of his predecessors. Notwithstanding, many of his own remarks possess much interest to the naturalist. The differences between the English and Irish hare has attracted the attention of naturalists within the last few years; and has also been remarked by sportsmen. Rutty, however, alluded to the fact of the well-known inferiority of the fur of the Irish hare in the manufacture of hats in his day. Mr. Thompson, who, some time since, made a communication to the Royal Irish Academy on the subject, has, however, just informed us, that "characters on which to found satisfactorily specific differences between the Irish and Alpine hare do not exist, either zoologically or anatomically, although the habits, or rather haunts, of the animals are so markedly different."

The work concludes with the details of his history of the weather. His hygrometer was a sponge dipped in brine, which, he adds, is an excellent magnet in respect to the moisture of the air, varying in weight nearly 200 grains. From 1717 to 1726 he used the diaries furnished by Isaac Butler, " astronomer," who was subsequently employed in the Physico-Historical Society to collect specimens of natural history, and was also engaged as "satellite." $(a)$ The diary of the weather terminates in 1765 , thus presenting a series of observations extending over forty-eight years, that being, as far as we are informed, the longest registration of the weather of Dublin now in existence.

In his Spiritual Diary he says of his preparations for this work: "From 1740 to 1745 I was engaged in the natural history of the county Dublin, and was led a long dance on birds, fishes, and fossils, and in compotations for information, and was greatly hurt in my spirituals by these means." It is certain that the turn of his mind disposed him strongly towards natural history. Botany in particular appeared to him so important, that he wished to diffuse a taste for it among his medical brethren, but with what success may be seen from the following entries in his diary. "20th, 8th mo., 1760 . A botanick walk, wherein in a manner solus, this noble and useful science being in utter contempt." "1st, 6th mo., 1767. A botanick walk on principle, but miserably attended; our medical, as well as ecclesiastical state is sick." "23rd, 3rd mo., 1769. Invited eight apothecaries to our botanick excursions on principle." " 29 th, 5 th mo.,

(a) See Preface to vol. i. of our present Series, page xxvi. 
1769. The botanick walk; $O$ the perverseness, the indolence, the ignorance, and the sin of the apothecaries!" " $29 \mathrm{th}, 5$ th mo., 1770. Yesterday's botanick walk gave peace and delight upon reflection, even as a testimony against the idle sons of Asculapius in this city, immersed in sloth and sensuality."

During his long professional life the Materia Medica was his favourite study, and all his other pursuits appeared to be followed only in subservience to this. He was ambitious to impart to it an exactitude and certainty which have been the great objects with all endowed with any adequate notion of its importance and its imperfections. Thus in his Diary, 6th month, 1756: "O! what infants we are in natural knowledge, and particularly in the Materia Medica after centuries of years, as appears in Le Clerc's History, whilst mere copyists are innumerable." Also, " 3 rd mo., 1760. God hath brought thee through a very thorny path of thy life. Now impends the great work of thy life, the Materia Medica. Lord preserve."

It was not completed till June, 1773: "Now finished the fair transcript of my Materia Medica, the principal work of my life ; a work of no present advantage to me, but $\bar{I}$ hope will prove so to others. Exercised a little Sabbath on this occasion." It was written in Latin, and sent over for publication to Holland. In the instructions concerning his will, written in February, 1774, he says, that last summer he had sent the Latin MS. of his Materia Medica to Holland, and that if the printing of it be delayed till after his decease, he gives the said MS. to Thomas Fowler, of Micklesham, Wilts, that he, with advice of Drs. Fothergill and Lettsom of London, may dispose of same; the profit to go to Thomas Fowler. It did not appear till some time in 1775 , the year of his death, and we have no means of ascertaining whether this labour of forty years was ever seen in print by the author $(a)$. It was dedicated to him in an elegant Latin preface by Van Royen of Leyden, dated 25th September, 1773 , in which he styles it desideratum novumque immensi laboris opus; yet declines to assent to some of his indentifications of ancient medicines, and particularly of hellebore and squill, regretting that the observations of the ancients should have become so generally useless, in consequence of their want of systematic arrangement of the subjects of natural history. The great rarity of the work renders it necessary that we should give the following brief epitome of its contents. The prologomena consists of

1. An alphabetical list of diseases, with the medicines suited for them, according to the Greek, Latin, and Arabian authors.

2. A classification of medicines according to their sensible qualities.

3. Do., according to their sensible operations.

4. A catalogue of simples having the same name as used by the ancients.

(a) The title of it is as follows:-“ Materia Medica, antiqua et nova, repuryata et illustrata sive de Medicaminum simplicium officinalium Facultatibns. Tractatus Authore Johanne Rutty, M. D. Opus XL. Annorum. Londini : F. \& C. Dilly. Rotterodami : Holsteyn \& Beman. 1775." 
5. Substances really different, though called by the same names by the ancients and moderns.

6. Substances called differently by us from the ancients.

7. Medicines of modern discovery, unknown to the ancients.

8. Remarkable medicines mentioned by the ancients, but not described by them so as to be certainly recognised.

9. Medicines derived from the Arabians or modern Greeks.

10. Medicines derived from America.

The body of the work is in alphabetical order, and under the head of each simple substance he gives its sensible qualities, its chemical properties according to the tests used at that time for determining acidity, alkalinity, astringency, \&c.; and lastly, an account of its physiological and medical properties. This latter class of facts is derived from the older authors, with some of his own observations subjoined. It is in the paucity of those that the work is most defective. He seems to have had an unjustifiable want of confidence in his own experience, which must have been both extensive and accurately recorded, and to have preferred to rely on the authority of the ancients, which, in this department, is peculiarly unworthy of confidence, not only by reason of the uncertainty of identification, but by the differences of race, of climate, of diet, and of habits in their patients, from our's. The work never reached a second edition, and it appears that it must have had a very limited sale, which is to be ascribed not only to the expensive quarto form in which it appeared, or to the Latin language in which it was written, and which at that time was rapidly falling into disuse; but principally to the circumstance that Dr. Cullen's excellent and practical work on the same subject appeared almost immediately afterwards, and soon secured to itself the suffrages of the British medical public, which it continued to retain for several succeeding years.

Thus the "Opus Quadraginta Annorum," which was intended by the author to place the Materia Medica on the basis of positive facts, and so to effect its total reformation, was neglected even from its first appearance, and passed rapidly into oblivion. It is now so scarce that not one of the public libraries of this city contains a copy.

From the time of his election into the Physico-Historical Society in 1744 he took a prominent and active share in their proceedings, and their thanks were repeatedly voted to him for his exertions. This Society met in the committee-room of the House of Lords, and numbered among its members several peers and other persons of distinction, who appear to have enlivened their philosophical pursuits by social entertainments conducted in a manner so little to the mind of Rutty, that they became the subjects of constant self-admonition and lamentation in his Diary. Thus: " 21 st, 5 th mo., 1756. Impends a drinking day at a Parliament meeting. Lord preserve from captivity and from the damnable sin. Accordingly marched off refreshed." "8th, 1st mo., 1756. Feasted with the new philosophers." 
" 5 th, 8th mo. A feast wherein a little swinish." " 11 th, 11 th mo. Feasted; idle, punning wit there not enough discouraged." "20th, 4th mo., 1757. Piggish at a feast." "22nd, 11th mo., 1758. Impends a feast. Take care." "23rd, 5th mo., 1759. A compotation disagreeable and beyond the holy bounds on a philosophical expedition."

The Medico-Philosophical Society was founded from the following circumstance: " 22 nd, 11th mo., 1756. A happy thought of presenting C. S. [Charles Smith, M. D., author of Natural History of Cork, \&c. ] with an old MS., partly laid a foundation for a most useful and virtuous society in this land of indolence. Blessed be the Lord! for I never dreamt of the good consequences I humbly hope entailed on this seeming accident." Rutty's numerous communications to this Society are still extant in the " Repository," the Minute-Book, and unpublished Memoirs and Proceedings of that body, now preserved in the libraries of the Royal Irish Academy, and the Association of the College of Physicians. Of the entire number of papers in the Repository, amounting to 230 , he contributed ninety-nine, principally on subjects relating to the materia medica, mineral waters, or natural history. In this Society, as elsewhere, he had to complain of the prevailing apathy with regard to science, and of the disposition to convert meetings ostensibly held for its promotion into scenes of conviviality. Thus: "16th, 4 th mo., 1759. O how little public spirit even in our temporals; I am forced to tug the oar almost alone in the service of a medical Society." " 19 th, 6 th mo., 1766. At the Medical Society almost alone : a sad world in nature and in grace. O where is public spirit!" " $3 \mathrm{rd}$, 10th mo., 1770. At our medical convention some real profit, but with a mixture of ungodly jokes. I fear I countenanced them too much. Must we go out of the world to fly from its contagion ?" After Rutty's death the Society became more and more negligent of the object of their institution, till at last they ceased to keep any records. They insensibly degenerated into a social club, dining at each other's houses on the most expensive scale ; and thus for many years before its fipal extinction, about twenty-five years ago, they gave occasion to a wellknown punster to say that from a Philosophical they had become a Fill-cesophageal Society $(a)$.

It must, however, in justice be confessed, that Rutty's notions on the subject of abstinence were not such as could be expected to meet with general acceptance either in this or any other country. He was, in fact, an ascetic; and probably so, both from holding that abstinence was meritorious in a religious point of view, as well as from having often experienced in his own person that depression and hebetude which the slighest infraction of its rules produces in some individuals. Thus : " 12 th, 4 th mo., 1754. Feasting rather beyond the holy bounds. O how difficult to keep innocent in company! Solitude is surely more eligible, yet society useful, but the sancti-

(a) For an account of this society see Preface to vol. i. of our present Scries, p. xxviii.-February, 1846. 
fied use of it very laborious." " $16 \mathrm{th}, 7$ th mo., 1775. Dogged; ate too much." "18th, 9th mo. Dined on bread and three glasses of wine and a repast of a domestic tea. 19th. A luxurious dinner on potatoes, onions, and cauliflowers, and three glasses of wine. 20th. Dined on broth this third day of my exercise of temperance, and was lightsome on it." "2lst, 10th mo. Dined on saffron cake and tea." "7th, 11th mo. Dined on bread and water to cure crapula." "12th, 7th mo., 1756. Dinner chocolate, and ate to live." " $3 \mathrm{rd}$, 3rd mo., 1758. Dinner on nettles." " 19 th, 5th mo. Dogged on fasting." " 13th, 9th mo., 1764. Ate bread and drank water for dinner." "17th, 11th mo., 1765. Dined on bread and water on principle." Though he smoked, yet it was not without compunctious visitings that "the pipe enslaved."

As a physician his practice was evidently not lucrative. His obscure style of living appears to have excluded him from coming into competition with the fashionable practitioners of the time, and his character for benevolence must also have caused him to be imposed upon by many. His complaints on the unrighteous detention of his fees are numerous, and will, no doubt, powerfully awake the sympathies of many of our readers. His indignation on this point was often roused to a degree which he found difficult to repress. " 13 th, 10th mo., 1755. Eleven patients, and not one fee, and my patience abused considerably. I muttered a little, I hope not unrighteously." "29th, 11th mo., 1755. The medical profession exhibits strongly the vanity and wickedness of the world, where the more work the less pay." "18th, 9th mo., 1756. A pretty handsome supply of paupers, but few of the rich." "26th,1st mo., 1760. Much medical work and little wages. Lord give patience!" " 17 th, 5 th mo., 1760. Eight patients and not a penny." In common with many who have allowed their services to be taken for nothing, he received his full share of ingratitude and of disregard of the value of his prescriptions: "lst, 7th mo., 1755. Contempt from a patient, and pretty calm under it." " 16 th, 8 th mo. A rencounter with a clamorous woman on a patient dying, and in dread of the mob, but was delivered, blessed be the Lord!" "26th. Great impertinence from a patient; borne tolerably, blessed be God!" "12th mo., 1757. Insulted and vexed by unrighteous contempt from even a poor patient, whom I was obliged to desert."

We have not been able to procure any account of the peculiar style of Rutty's practice as a physician. The merits of the medical practitioner, often unknown to, and even unappreciated by those whose lives have been saved by them, are forgotten along with the occasions which have called them into action, and the memory of them usually perishes with the existing generation. He does not appear to have held any hospital appointment, but availed himself of the opportunities of witnessing the practice of Steevens' Hospital, as he alludes to it in his Materia Medica. Only one professional letter has come into our hands, which we insert as a specimen of his style and character in this point of view. It was addressed to 
the grandfather of the gentleman who obligingly lent it to us, and was intended for him and his wife, which accounts for the use of the plural pronoun.

\section{To Joshua Strangman, Mountmellick:}

Dublin, $\frac{3^{3}{ }^{3} \text { mo. }}{17} 174$.

"Loveing Frriend,--In answer to thy letr. I received yesterday I should be glad it were in my power to send you any directions, that might be to the purpose, and of real service, at this distance.

"To be enabled to judge whether either of $y^{\mathrm{e}}$ waters you mention, or any other medicine, may be proper, all $\mathrm{y}^{\mathrm{e}}$ lights that can be given in so difficult and long depending a case are little enough, and therefore I can give no judgment of this or that method on $\mathrm{y}^{\mathrm{e}}$ present representations of $y^{\circ}$ cases until I have a more minute account from your physician, and particularly of her present degree of strength, and the variation of it, and of $y^{e}$ pulse from their former state, and what medicines have been already ordered, besides several other particulars that must occur: without this precaution patients run giddily in to a right or wrong course, and had better have been quiet and done nothing.

"I am willing to serve you to $y^{e}$ utmost of my power, and have told you $\mathrm{y}^{\mathfrak{e}}$ road in which alone $\mathrm{I}$ can do so, who am,

$$
\text { "Thy sincere ffriend, }
$$

We are indebted to Dr. Roget for the following letter of Rutty's to his cousin, Dr. W. Rutty, who was second Secretary to the Royal Society, from 1727 to 1730 . It is one of many from the same hand, still preserved in the archives of that body:

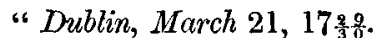

"Dear Cousin, - I am favoured $w^{\text {th }}$ thine of Feb 6 by wc. I find thou hast done me much more honour $\mathrm{y}^{\mathrm{n}}$ ever I expected, indeed I wish my papers had $b^{\mathrm{n}}$. better prepared for so publick an examination. However I am greatly obliged to thee for those judicious remarks upon it, and will endeavour to convert $y^{\mathrm{m}}$ to $\mathrm{y}^{\mathrm{e}}$ advantage of my subject as much as 1 can. Thou very justly observest $\mathrm{y}^{\mathrm{t}} \mathrm{w}^{\mathrm{t}}$. is likely to take up a good $\mathrm{p}^{\mathrm{t}}$ of one's time ought to answer in its usefulness and I am so far from being offended at thy freedom in comunicating thy sentim ${ }^{\text {ts }} \mathrm{y}^{t}$. I should deem no friendship valuable where $y^{t}$ liberty were not allowed. However I cannot but observe one or two things upon yor remarks. First as to y: determination of how far $y^{e}$. modern medicines were known to $y^{e}$ ancients, I cannot help thinking this to be a considerabe article, althô at last there shou'd be left but a very small number of those $y^{t}$ are comon to us and them, since this is absolutely necessary in order to a rejection of uncertainties out of $u^{\mathrm{x}}$ accounts of $y^{\mathrm{e}}$ powers of simple medicines, $w^{\text {th }} w^{\text {elt }}$ uncertainties $y^{t} . y^{\text {e }}$. present acco ${ }^{\text {ts }}$ are pretty much perplex'd whilst $y^{e}$ very words of Dioscorides are transcribed and apply'd to different medicines is allow'd. But when onee ye me- 
dicines concerned shall be reduced to comon, doubtful \& new, as there is a necessity in an affair of this nature to make use of authorities for facts, we shall know wt authors to have recourse to under cach head, $w^{\text {ch }}$ otherwise cou'd not be done. So $y^{t}$ I cannot but look upon thy article to be like removing the rubbish in order to build securely,

“ The difficulty attending an accot of tast \& smell from not only $o^{r}$ inability to express by words many ideas we receive $y^{t}$. way but also from $y^{c}$. diversity of both in different persons must be allowed in a great measure, but still I cannot think $\mathrm{y}^{\mathrm{t}}$ this article can be totally rejected without great injury.

"The difficulties mentioned are allow'd to obtain in many medicines \& accordingly wherever $\mathrm{y}^{\circ}$ tast and smell is uncapable of description it shall be acknowledged nor shall it be presumed to class such medicines from thence: We must not expect but to find anomalies here as well as do $y^{e}$. botanists in $y^{\mathrm{r}}$. distributions: But from

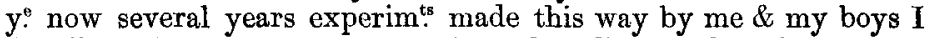
do affirm $y^{t}$ in a very great number of medicines, there is not only such an uniformity in o. accounts but there is in $y^{0}$ medicines such a natural, evident, unstrain'd affinity between $y^{m}$. in that respect $w^{\text {eh }}$ also for $y^{\text {e }}$ most part holds in correspondent virtues that to suppress this were to suppress perhaps $\mathrm{y}^{e}$. best list of succedanea $\mathrm{y}^{t}$. can be given.

"It is always to be supposed $y^{t}$ useless subtilty in $y^{e}$ subdivisions of tasts $\&$ smells is avoided \& $\mathrm{y}^{\mathrm{t}} \cdot \mathrm{y}^{\mathrm{e}}$. predominant evident tasts only are noticed $\&$ such in $w^{\text {ch }} y^{\mathrm{e}}$ generality of mankind will pronounce the same thing upon trial.

"But not to carry this article to fondness \& althô this be free from an objection attending $y^{e}$. chymical analysis $y^{t}$. it alters $y^{e}$. natural state of bodies, yet tast \& smell are allow'd to be very defective withot other helps \& so accordingly as you very well observe $y^{e}$. chym! analysis \& expts $y^{e}$ mechanick properties, $y^{e}$ obvious texture, $y^{\mathrm{e}}$. menstruums in $\mathrm{w}^{\text {eh }}$ they dissolve as far as water $\&$ spirit of wine are also designed to be adopted. I wou'd fain call in all pertinent assistances \& give to each its due weight.

"I cannot but be apprized of $\mathrm{y}^{\mathrm{e}}$ objection $\mathrm{y}^{\mathrm{t}}$ he $\mathrm{y}^{\mathrm{t}}$. grasps at all loses all, one man's life not being long enough \& can only answer $y^{t}$ I have a prospect of a considerable share of leisure, $y^{t}$ I have made a little further progress in $y^{t}$ affair already $y^{n}$ appear'd in my specimen \& yt I am determined to take care abt. securing it to posterity if I leave it unfinish'd.

"For an accot of $y^{e}$. laurel water I refer to $D^{r}$. Sotherland in Cheapside to whom $\mathrm{y}^{\mathrm{e}}$ acco. was transmitted by $\mathrm{D}^{\mathrm{r}}$. Weld of this city. Dr. Madden indeed is now upon some further exp.a abt. it $\&$ hopes $w^{n}$. he has finish'd 'em to transmit 'em by me to thee.

"In y. mean time I am very much " thy affectionate cousin "JNu. Rutty.

"Pleasc to direct for mu at Theophilus Harrison's, Apothecary in Fishamble street." 
This letter refers to his paper on Laurel Water, which was published by the Royal Society the same year; and particularly to his work upon the Materia Medica, which occupied so much of his time and thoughts.

Although not strictly within the subjects belonging to this Journal, yet the character of Rutty would be inadequately understood did we omit to state his sentiments on the subject of religion. All his labours and his whole course of life were influenced by an ardent and constant desire to regulate his conduct according to the precepts of the Gospel. His tenderness of conscience was such, that he even accused himself of undue attention to temporal things when occupied in the studies of natural history and the Materia Medica. Reflections of self-reproach on this head are scattered throughout the Diary. Those infirmities of temper which are usually disregarded, provided they are concealed or polished down so as not to offend society, were to him subjects of constant animadversion and correction. This appears from such entries as the following: "Snappish-scolded too vehemently-mechanically and sinfully dogged_brittle upon a slight occasion_-snappish on a cross call_ vociferation too loud to my servant-a little crabbed with two incurables," \&c.

A warmly-attached member of the Society of Friends, and an elder of that body, he constantly mourned over the instances of declension in zeal and discipline which came under his view. He seems to have occupied that peculiar position among them which can never attract popularity. He who wishes to maintain long-established institutions in all their integrity, and yet to oppose existing abuses, which have grown up along with them, will be acceptable to neither Whigs nor Tories. He has nothing wherewith to gratify the lovers of change and innovation, and is regarded with apprehension by those to whom abuses have become sources of comfort or profit. No party gathers round him; he is considered a troublesome man, and soon finds how difficult it is to stem the corrupting influences which sooner or later deteriorate all human institutions. Rutty had his full share of such disappointments, yet to the last he indulged in no bitterness, but contented himself with self-examination and the diligent performance of his own duties.

His Christianity was adorned by a truly Catholic spirit. Severe to himself alone, he looked with complacency on all who professed to derive their religion from the sources of revelation. At the beginning of every month he held a conference with a member of another religious body, whom he calls "my brother," in order to promote their spiritual improvement. He highly esteemed the writings of Bishop Ken and other divines of the Church of England. When Wesley was in Dublin two interviews are mentioned in their respective diaries, equally gratifying to each. Of Dr. Doddrige, the famous Independent, he writes: "1764. Read Dodderige, a laconic, pathetic, energetic, and heart-searching minister. $O$ what a pigmy $I$ am before him!" Of Roman Catholic authors he says: "1765. Thomas a Kempis is oue of my companions in solitude, and, blessed be 
the Lord! I relish him better than ever;" and again: "1771. A sweet occurrence in a mass-book entitled The Path to Paradise, where there is a collection, in one view, of twenty-seven petitions, truly apposite and pertinent to the state of aimost every Christian. Truly I was surprised to find so much gold in a mass-book."

In 1771 he had an attack of paralysis, which is thus noticed: "17th, 8 mo. A memorable call; a slight hemiplegia in tottering limbs, and a faultering tongue." " 21 st. The paralytic disease increases." During the following month he recovered, after a confinement of three weeks, and was able to resume most of his ordinary occupations till December, 1774, when he writes: "The marasmus senilis is come; a deep hollow in my thigh." His last entry is on the 8th of that month: "The voice of God now sounds louder in my great infirmity of being scarcely able to bear the cold." $(a)$

The apothecaries' account of medicines furnished to him in his last illness (now before us) contains frequent repetitions of large quantities of sulphur, with occasionally spirits of hartshorn and guaiacum, till the 22nd of April, when he commenced the use of an "astringent cordial," which was continued to the $25 \mathrm{th}$. He died on the next day, the 26th of April, 1775, being in the seventyfourth year of his age. (b)

He was interred in the Friends' burying-ground in York-street (the site of the present College of Surgeons) on the $27 \mathrm{th}$, and the entire expenses of his funeral (from the executors' account) did not amount to three guineas. He had provided for this by the following clause in his will, viz.: "And in testimony against the vain pomps of the world, I desire that my corpse may be conveyed to the place of interment in no other covering than a plain deal coffin."

His property, which principally consisted of copyhold lands in Wiltshire, he bequeathed equally amongst a number of children of his brothers and sisters, and a cousin. He also left several legacies to objects of charity.

In 1755 his residence was in Pill-lane; he resided for many years in the house in which he died, at the eastern corner of Boot-lane and Mary's-lane, which still remains, though much out of repair. He held the drawing-room floor of this house at a rent of $£ 10$ per annum.

His Spiritual Diary passed through two editions, and was edited by some person of a different religious denomination, who added a commendatory preface. He has also subjoined a testimony concerning Rutty, drawn up the year after his death, and signed by a

(a) Wesley's Journal, 6th April, 1775. "I visited that venerable man, Dr. Rutty, just tottering over the grave, but still clear in his understanding, full of taith and love, and patiently wating till his change shall come."

(b) Our readers, are, we presume, aware, that, up to the year 1805 , the site on which the present College of surgeons stands was occupied as a Quaker's burial ground. Prior to the erection of that building, any remains that could be collected were removed to the present cemetery in Cork-street. 
number of leading members of the truly benevolent and aimable society to which he belonged, from which we cannot omit the following extracts:

" He was esteemed a skilful and successful physician, and was well beloved in this city, being an exemplary and useful member both of civil and religious society. His temper appeared pleasing and well guarded; mild in reasoning with persons from whom he differed in judgment, even on important and interesting subjects. He was accounted temperate in eating and drinking. He generally used to rise early in the morning to his studies.

"He was plain in dress and address; he declined ostentation, and adopted a lowly way of living; he was charitable to the poor, many of whom almost daily resorted to bim for his advice and help; others, prevented by their distempers, he visited at their dwellings, and exercised a tender care toward them.

"The remembrance of his useful services has endeared his memory to us and to many more. In a good old age he departed this life with thanksgiving to God, and, we believe, in the fruition of the renewed foretaste of those good things which God has in store for those that love him."

We cannot terminate this memoir without expressing our acknowledgments to Messrs. Jonathan Hill, Samuel Bewley, and Forbes. Unless we had obtained their assistance many facts had remained unknown, for they furnished us with the means of learning much which otherwise had been lost for ever. The first-mentioned gentleman received the account of many particulars from his venerable father, who was intimately acquainted with Rutty.

\section{LIST OF DR. JOHN RUTTY'S PUBLICATIONS.}

\section{0. - A Dissertation on Laurel Water. In Philosophical Transactions.}

1732._" Extract of a Letter from John Rutty, M. D. to Dr. Mortimer, Sec. R. S., concerning the Poison of Laurel Water."Phil. Trans.

1751.- "A History of the Rise and Progress of the People called Quakers in Ireland, from 1653 to 1700 , \&c., \&c. First compiled at the Request of their national Meeting, by Thomas Wight of Cork. Now revised and enlarged, to which is added, A Continuation of the same History to the Year of our Lord 175l; with an Introduction describing summarily the Apostacy of the Professors of Christiany from primitive Simplicity and Purity through its several Stages, and the gradual Reformation from thence; and a Treatise of the Christian Discipline exercised among the said People. By John Rutty. Dublin: printed by J. Jackson, in Meath-street, Bookseller. 1751." 4to. pp. 484. The introduction amounts to seventyeight pages.

1752._" $\Lambda$ Treatise on Christian Discipline." This work we have not seen; it is thus defined in the Anthologia Hibernica, vol. ii., p. 259 ; but it is probably the work described above. 
1756.- " Account of the Copper Springs lately discovered in Pennsylvania. By John Rutty, M. D., of Dublin. Communicated by Mr. Peter Collinson, F. R. S."?-Phil. Trans.

1757.-. An Essay towards a natural, experimental, and medicinal History of the Mineral Waters of Ireland; wherein, the several impregnating Minerals being investigated by a Series of Experiments, each Water is reduced to its proper Class. The Virtues of such as have been used are given from practical Observations. Divers new Waters, especially of the sulphureous and vitriolic Kind, are enumerated, and more accurately described than hitherto. The whole illustrated with Tables, exhibiting a clear View of the Experiments in concert, and a Comparison of the Irish to the English and other foreign Waters." By John Rutty, M. D. Dublin 8vo. 1757. pp. 478.

An edition in quarto was published in the same year.

1759.- " Thoughts on the different Impregnations of Mineral Waters, more particularly concerning the Existence of Sulphur in some of them. By John Rutty, M. D."-Phil. Trans.

This paper was in answer to Lucas's work, already referred to.

1760.- " Of the Vitriolic Waters of Amlwch, in the Isle of Anglesey; with occasional Remarks on the Hartfell Spaw, described in the first Volume of the Edinburgh Essays and Observations, Physical and Literary, and in the forty-ninth Volume of the Philosophical Transactions; and their Comparison with other Waters of the same Class. By John Rutty, M. D."-Phil. Trans.

1762.- "The Analysis of Milk and the different Species thereof." Dublin. 8vo. pp. 19. 1762 (written in 1758).

1762. - "The Argument of Sulphur or no Sulphur in Waters discussed; with a Comparison of the Waters of Aix-la-Chapelle, Bath, and Bristol. Wherein the Sulphur is restored to the two first, and the Contents of the last are ascertained with a somewhat greater Degree of Precision than in the Essay of the late Adept, and the injured Credit of divers other salutiferous Springs is vindicated, from the Evidence of that A uthor's own Experiments, corroborated by many others; being the Subjects of a Correspondence between the Author of the Methodical Synopsis of Mineral Waters and W. IR., Esq., and some others. And to this is subjoined a more explicit Account of the Nitre of the Ancients."-8vo. pp. 109. Dated Dublin, 7th, 7 mo., 1762. Printed by Alex. M'Culloh (see p. 561).

1770._." A chronological History of the Weather and Seasons, and of the prevailing Diseases in Dublin, with their various Periods, Successions, and Revolutions, during the Space of forty Years; with a. comparative View of the Difference of the Irish Climate and Diseases, and those of England and other Countries. By John Rutty, M. D."-London: Robinson and Roberts. 8vo. 1770. pp. 340 .

1772. - "An Essay towards a Natural History of the County of Dublin, accommodated to the noble Designs of the Dublin Society; affording a summary View, first, of its Vegetables, with their mechanical and economical Uses, and as Food for Men and Cattle; a Ca- 
talogue of our vegetable Poisons; and a Botanical Calendar, exhibiting the respective Months in which most of the Simples in Use are found in Flower. Second, of its Animals. Third, of its Soil, and the State of its Agriculture; its Fossils, Mines, Minerals, and some lately discovered Mineral Waters, particularly the Sulphureous Water at Lucan, and its Medicinal Virtues, from practical Observations. Fourth, of the Nature of the Climate, from the Diaries of the Weather kept in Dublin for fifty Years past: interspersed with Meteorogical and Economical Observations. By John Rutty, M. D."'-2 vols. 8vo. Dublin: printed for the Author, by Sleater, in Castle-street, and Jackson, in Meath-street. 1772. Vol. i. pp. 329; vol. ii. pp. 488.

1775._- Materia Medica, antiqua et nova, repurgata et illustrata, sive De Medicaminvum simplicium officinalium Facultatibus. Tractatus Authore Johanne Rutty, M.D. Exhibens, I. Simplicia nobis veteribusque communia de quibus fere quicquid veri aut verosimile apud Græcos veteres et Recentiores Latinos et Arabes reperitur, Religitur, ennaratur, et Notis illustratur. II. Simplicia Dubia et noviter detecta quorum Vires indagantur, et Observationibus atque Experimentis Recentiorum illustratur. Adjectis Classibus simplicium secundum Qualitates et Eperationes sensibiles." -Opus xl. Annorum. Londini: E. \& C. Dilly. 1775. 4to. pp. 560. Rotterodami: Holsteyn \& Breman.

This publication was the last during Dr. Rutty's life-time.

\section{POSTHUMOUS PUBLICATIONS.}

1775.- " Observations on the London and Edinburgh Dispensatories," published the year after his death.-See Anthologia Hibernica, vol. ii. p. 259. This work likewise contains a brief and very incorrect notice of Dr. Rutty.

1777.-A Spiritual Diary. First Edition.

1796. - " A Spiritual Diary and Soliloquies. By John Rutty, M. D., late of Dublin." Second Edition. London: Phillips. 8vo. 1796. pp. 421. Diary commences 13th September, 1753; terminates December, 1774.

We had hoped to have been able to present our readers with a summary, or at least catalogue, of Rutty's papers preserved in the Manuscripts of the Medico-Philosophical Society, but our space does not at present admit of it. We intend to redeem our promise very shortly, and print several of the communications contained in these valuable records.

Dr. Rutty having been a member of the Society of Friends accounts for our not being able to present our readers with a Portrait this time. 